Scientia Agricola

http://dx.doi.org/10.1590/0103-9016-2014-0026

\title{
Aggregation agents and structural stability in soils with different texture and organic
} carbon contents

\author{
María Eugenia Carrizo ${ }^{1}$, Carlos Agustín Alesso ${ }^{1}$, Diego Cosentino², Silvia Imhoff ${ }^{3 *}$
}

${ }^{1}$ National University of Litoral/Faculty of Agricultural Science - Dept. of Environmental Science, Kreder 2805 - S3080HOF

- Esperanza - Argentina.

UUniversity of Buenos Aires/Faculty of Agronomy - Dept. of Natural Resources and Environment/National Council of Scientific and Technical Researches, Av. San Martín, 4453-C1417DSE - Buenos Aires - Argentina ${ }^{3}$ National University of Litoral/Faculty of Agricultural Science - Dept. of Environmental Science/National Council of Scientific and Technical Researches, Kreder 2805-S3080HOF - Esperanza - Argentina

*Corresponding author <simhoff@fca.unl.edu.ar>

Edited by: Leônidas Carrijo Azevedo Melo

Received January 22, 2014

Accepted May 14, 2014
ABSTRACT: The flat pampas in the state of Santa Fe in Argentina have soils with high silt content, variable carbon content, and diverse degrees of structural degradation. Aggregate stability has been used as an indicator of the structural condition of the soil. This study aimed to quantify the effect of the addition of crop residues and root activity on the agents of aggregation and mechanisms of aggregate breakdown in soils with different carbon contents and textures cultivated under no-till. An experimental trial was conducted on a loamy soil (Typic Hapludoll, Santa Isabel series) and a silty soil (Typic Argiudoll, Esperanza series) under controlled conditions for 112 days with the following treatments: (i) with and without wheat plant growth and (ii) with and without addition of wheat residues. Soil structural stability by a method allowing for differentiation of aggregate breakdown by slaking, mechanical effect and microcracking, total organic carbon content, particulate organic carbon, glomalin and carbohydrate fractions was assessed. In general, the addition of residues and the presence of plant with active roots increased the presence of all aggregation agents and decreased aggregate breakdown processes in both soils. Soluble carbohydrates and proteins related to glomalin were the most important aggregating agents and their function was to reduce the magnitude of breakdown mechanisms, slaking and microcracking, evidencing a greater impact on the silty soil.

Keywords: glomalin, carbohydrates, crop residues, active roots

\section{Introduction}

The flat pampas of the Santa Fe State in Argentina have soils with variable carbon content and non-expandable minerals (silt and illitic clay) in the upper horizon that entail their low structural regeneration capacity and hence their vulnerability to physical degradation (Pecorari et al., 1990; Sasal et al., 2006). Thus, the recovery of the soil structure poses a great technological challenge (Varela et al., 2011).

Soil organic matter and texture (clay content) are the main abiotic binding agents in the formation and stabilization of aggregates (Tisdall and Oades, 1982; Chenu et al., 2000; Duchicela et al., 2012; Portella et al., 2012), while soil microbes (bacteria and fungi) and plant roots have been reported as key biotic aggregating agents (Chaudhary et al., 2009; Duchicela et al., 2013). The effects of root and the crop residue addition on the stability of soil aggregates were widely evaluated, with varying results that were attributed to the existence of several mechanisms of aggregate breakdown and methodologies (Materechera et al., 1994; Amezketa, 1999; Taboada et al., 2004; De Gryze et al., 2005; Denef and Six, 2005; Abiven et al., 2007). Le Bissonnais (1996) suggested a method to differentiate the mechanisms causing aggregate breakdown, the way in which the water acts on the soil, and the soil physical and chemical properties that influence breakdown. This method was very efficient for studying silt loam soils, such as those prevailing in the flat pampas in Santa Fe (Cosentino et al., 2006; Maqubela et al., 2012).
Aggregating agents have also been quantified by means of various indicators, such as those that depend on soil organic matter (total carbon, particulate carbon) and those that are related to microorganism activity (glomalin, total carbohydrates) (Wright and Upadhyaya, 1998; Six et al., 2000; Annabi et al., 2007). However, few studies have evaluated binding agents that affect aggregate stability and their influence on aggregate breakdown mechanisms. Our hypothesis is that incorporating organic matter in the soil favors the increase of substances involved in aggregate stability and decreases slaking mechanisms and mechanical breakdown; this being more evident in soils with higher silt content. This study aimed to quantify the effect of incorporating crop residues and plants (active roots) on the presence of several aggregation agents and on the aggregate breakdown mechanisms in soils with different carbon contents and textures cultivated under no-till.

\section{Materials and Methods}

Soils used in this experiment were a Typic Argiudoll, Esperanza series, and a Typic Hapludoll, Santa Isabel series, located at the center $\left(31^{\circ} 26^{\prime} 08^{\prime \prime} \mathrm{S}, 60^{\circ} 56^{\prime} 43^{\prime \prime}\right.$ $\mathrm{W})$ and south $\left(33^{\circ} 93^{\prime} 62^{\prime \prime} \mathrm{S}, 61^{\circ} 57^{\prime} 87^{\prime \prime} \mathrm{W}\right)$ of the state of Santa Fe, Argentina. At each location, soil samples $(\mathrm{N}=$ $20)$ were collected from the top layer $(0-20 \mathrm{~cm})$ of a plot whose soil had been managed under no-till for the last ten years with agricultural rotations. This study was carried out manually, using a shovel, to avoid disturbing the natural structure of the soil as far as possible. The vegetation cover and litter layer were pushed aside prior to sampling. 
Soil samples were placed into bags and shipped to the laboratory. On arrival they were immediately crumbled by hand at field moisture along their natural fissures. After that, soil samples were air-dried and sieved to obtain soil aggregates of less than $2 \mathrm{~mm}$. Then, they were bulked to obtain a composite sample of each soil (about $100 \mathrm{~kg}$ ) that was used to set up the greenhouse experiment. This procedure was adopted as it both facilitates the evaluatation of the formation and stabilization of soil aggregates, and has a starting point that is a controlled soil structure, thereby avoiding confusion with previously uncontrolled disaggregation of the sample in the field or during subsequent sampling (Le Bissonnais, 1996).

A subsample from each composite sample was taken for measuring the following: particle size distribution (Gee and Or, 2002), total organic carbon (TOC) estimated from readily oxidable carbon (IRAM, 2007), soil reaction $(\mathrm{pH})$ by potentiometric method in a $1: 2.5$ soilwater ratio, electrical conductivity (EC) in the saturation extract and cation exchange capacity (CEC) by extraction with ammonium acetate $1 \mathrm{M} \mathrm{pH} 7$ and ammonium postdetermination by Kjeldahl distillation. The analytical methods follow standardized Argentinian methodology (SAMLA, 2004). The chemical and physical characteristics of the soils are shown in Table 1.

\section{Greenhouse experiment}

Experimental setup and treatments - Two greenhouse experiments were carried out simultaneously, one for each kind of soil (Table 1). The experiments were conducted under controlled temperature $\left(10-30{ }^{\circ} \mathrm{C}\right)$ and humidity (50-80\%) conditions. The composite samples, consisting of aggregates less than $2 \mathrm{~mm}$ in size, were placed in $5 \mathrm{~L}$ capacity pots, with an approximate bulk density of $1.3 \mathrm{~g} \mathrm{~cm}^{-3}$. The additional contribution of organic substances to the soils was applied using the roots of wheat in active growth $(+\mathrm{pl})$ and residues $(+\mathrm{res})$ which, in turn, differentially affected soil organic matter fractions and the microorganism activity. The following treatments were administered in triplicate: (i) without wheat plant growth and without addition of residues

Table 1 - Physical and chemical characterization of soils.

\begin{tabular}{|c|c|c|}
\hline Soil properties & $\begin{array}{l}\text { Typic Hapludoll, } \\
\text { Santa Isabel series }\end{array}$ & $\begin{array}{l}\text { Typic Argiudoll, } \\
\text { Esperanza series }\end{array}$ \\
\hline Clay $\left(\mathrm{g} \mathrm{kg}^{-1}\right)$ & 160 & 240 \\
\hline Silt $\left(\mathrm{g} \mathrm{kg}^{-1}\right)$ & 430 & 710 \\
\hline Sand $\left(\mathrm{g} \mathrm{kg}^{-1}\right)$ & 410 & 50 \\
\hline Texture & Loamy & Silty-loamy \\
\hline TOC ( $\left.\mathrm{g} \mathrm{kg}^{-1}\right)$ & 21.1 & 15.3 \\
\hline pH (soil: water $1: 2.5$ ) & 5.9 & 6.1 \\
\hline $\mathrm{EC}\left(\mathrm{dS} \mathrm{m}^{-1}\right)$ & 0.7 & 0.8 \\
\hline $\mathrm{CEC}\left(\mathrm{mmol} \mathrm{kg}^{-1}\right)$ & 164 & 155 \\
\hline
\end{tabular}

$\mathrm{TOC}=$ total organic carbon; $\mathrm{EC}=$ electrical conductivity; $\mathrm{CEC}=$ cation exchange capacity. (-pl -res), (ii) without wheat (Triticum aestivum L.) plant growth and with addition of residues (-pl + res), (iii) with wheat plant growth and without addition of residues $\mid+$ pl -res) and (iv) with wheat plant growth and with addition of residues $(+\mathrm{pl}+\mathrm{res})$. In treatments with plants, four wheat plants were grown per pot adding all necessary nutrients with Hoagland solution (Hoagland and Arnon, 1950). For stubble treatments $1-\mathrm{cm}$ long wheat residues were manually mixed into the top $10 \mathrm{~cm}$ soil layer at a rate equivalent to $5,000 \mathrm{~kg} \mathrm{ha}^{-1}$ dry matter, before sowing the seeds. All pots were subjected to wetting and drying cycles varying the water content between the humidity corresponding to $10 \%$ aeration and one third of the total water content at field capacity moisture. Replenishment was carried out with deionized water or Hoagland solution until the set value was reached.

When wheat plants began their senescence /day 112) the experiments were concluded to prevent significant root decomposition (Denef and Six, 2005). The aerial part of the plant was cut and the soil of each pot was allowed to dry off in the air until soil moisture was about $20 \%$. The top ten centimeter soil layer of each pot was extracted and gently crumbled by hand through its natural weakness planes. Great care was taken to avoid damaging the natural aggregates. Then, the soil was sieved to obtain an adequate amount of aggregates between 3 and $5 \mathrm{~mm}$. After sieving, coarse organic matter (free roots and plant debris) was removed and soil samples were screened for each determination.

Determination of soil physical and chemical parameters - Aggregate stability was determined in accordance with the method described by Le Bissonnais (1996) since this method takes the various mechanisms of aggregate breakdown into account (i.e. slaking, breakdown by differential swelling, mechanical breakdown and physicochemical dispersion), and it was designed to enable comparison of soils or climatic conditions for a given soil. This method consolidates several existing methods of measuring aggregate stability into the following three disruptive pre-treatments with different moisture and energy conditions: fast wetting (FW), mechanical breakdown (MB) and slow wetting (SW). Each pre-treatment was performed in triplicate on 3-5 $\mathrm{mm}$ aggregates dried at $40^{\circ} \mathrm{C}$ for $24 \mathrm{~h}$ to standardize the initial moisture content obtained from each pot.

For the fast wetting $(\mathrm{FW})$ pre-treatment, about $5 \mathrm{~g}$ aggregates were quickly submerged in $50 \mathrm{~mL}$ of deionized water for $10 \mathrm{~min}$. In the case of the mechanical breakdown (MB) pre-treatment, aggregates were submerged in ethanol for 30 minutes. The ethanol was then removed and aggregates were immersed in $250 \mathrm{~mL}$ distilled water in an Erlenmeyer flask and quickly shaken ten times making semicircular movements. Subsequently, samples were kept at rest to allow particle sedimentation and excess water removal. In the slow wetting (SW) pre-treatment, $5 \mathrm{~g}$ aggregates were capillary wetted at -3 $\mathrm{cm}$ suction table for $30 \mathrm{~min}$. 
After each pre-treatment, samples were gently transferred to a $0.05 \mathrm{~mm}$ sieve and submerged in ethanol for five cycles with a Feodoroff mixer. Aggregates retained on the sieve were dried at $40{ }^{\circ} \mathrm{C}$ and gently sieved using a column of six sieves $(2,1,0.5,0.2,0.1$ and 0.05 $\mathrm{mm})$ for aggregate size distribution. The mean weight diameter (MWD) was calculated as follows:

$\mathrm{MWD}=\sum_{\mathrm{i}=1}^{\mathrm{n}} \mathrm{x}_{i} \cdot \mathrm{w}_{i}$

where: $\mathrm{x}_{\mathrm{i}}$ is the mean diameter of the size fraction $i$ that corresponds to the mean aperture of the adjacent sieves, and $\mathrm{w}_{\mathrm{i}}$ is the proportion of the total sample weight remaining on each sieve after sieving.

Total organic carbon (TOC) was estimated in triplicate from easily oxidable carbon with a recovery factor of 0.77 (IRAM, 2007). This method consists of an oxidation of organic carbon by wet excess of potassium dichromate and spontaneous heating by sulfuric acid and final assessment of the chromium reduced to $\mathrm{Cr}^{3+}$ with a ferrous salt. Particulate organic carbon (POC) by physical fractionation was obtained as described by Irizar et al. (2010). In the material retained on the $0.053 \mathrm{~mm}$ sieve organic carbon content was determined according to IRAM (2007).

Carbohydrate content was determined in triplicate in each sample from $1 \mathrm{~g}$ of soil $(<1 \mathrm{~mm})$ using the sulfuric acid-phenol procedure (Dubois et al., 1956). Hot water extractable carbohydrates (HWEC) were digested with $10 \mathrm{~mL}$ distilled water at $80^{\circ} \mathrm{C}$ for $24 \mathrm{~h}$. Total carbohydrates (TC) were obtained from a concentrated acid hydrolysis which consisted in treating the soil with $2 \mathrm{ml}$ $12 \mathrm{M} \mathrm{H}_{2} \mathrm{SO}_{4}$ for $16 \mathrm{~h}$ at room temperature. Subsequently, this mixture was diluted to obtain a concentration of 1 $\mathrm{M} \mathrm{H}_{2} \mathrm{SO}_{4}$ and then placed in a culture oven at $100{ }^{\circ} \mathrm{C}$ for $5 \mathrm{~h}$ (Puget et al., 1999). Hydrolysis carbohydrate content was measured by colorimetry with glucose solutions as standards.

Glomalin has been operationally defined as glomalin-related soil protein (GRSP) (Rillig, 2004). This designation is used since the Bradford method is not a specific test for a particular protein. We used the procedure described by Wright and Upadhyaya (1996), through an extraction with sodium citrate in an autoclave at $121^{\circ} \mathrm{C}$, centrifuged at $10,000 \times \mathrm{g}$ for $20 \mathrm{~min}$. For the easily extractable fraction (EE-GRSP) $20 \mathrm{mM}$ sodium-citrate $\mathrm{pH}$ 7.0 were used, autoclaved for $30 \mathrm{~min}$. The total fraction (GRSP) was extracted with $50 \mathrm{mM}$ citrate pH 8.0 autoclaved for $60 \mathrm{~min}$, repeating cycles until a clear color extract was obtained. Quantification of both fractions was performed by applying the Bradford method using bovine serum albumin as standard.

\section{Statistical analysis}

To determine the effect of treatments a variance analysis and subsequent multiple comparison Tukey's test $(p<0.05)$ were performed. The relationship between the mean weight diameter (MWD) resulting from different pre-treatments and aggregation agents was assessed by using canonical correlation analysis.

\section{Results and Discussion}

\section{Effect of the treatments on different aggregating agents}

All variables were different $(p<0.05)$ in the soils tested, except for the concentration of EE-GRSP (Table 2). Total organic carbon did not present any differences between treatments. In contrast, particulate organic carbon (POC) increased in both soils with the addition of residues or the presence of active roots. The greater POC enhancement was observed in $+\mathrm{pl}+\mathrm{res}$, with $61 \%$ in

Table 2 - Total organic carbon (TOC), particulate organic carbon (POC), hot water-extractable carbohydrates (HWEC), total carbohydrates (TC), glomalin-related soil proteins (GRSP) and easily extractable soil proteins (EE-GRSP) for each Typic Hapludoll, Santa Isabel series, and Typic Argiudoll, Esperanza series, treatment.

\begin{tabular}{|c|c|c|c|c|}
\hline \multirow[t]{2}{*}{ Variables } & \multicolumn{4}{|c|}{ Typic Hapludoll, Santa Isabel series } \\
\hline & -pl-res & $-p l+$ res & $+\mathrm{pl}$-res & $+\mathrm{pl}+\mathrm{res}$ \\
\hline TOC $\left(\mathrm{g} \mathrm{kg}^{-1}\right)$ & $17.9 \mathrm{Aa}$ & $18.5 \mathrm{Aa}$ & $18.5 \mathrm{Aa}$ & $18.6 \mathrm{Aa}$ \\
\hline POC $\left(\mathrm{g} \mathrm{kg}^{-1}\right)$ & $3.3 \mathrm{Ac}$ & $3.8 \mathrm{Ab}$ & $4.1 \mathrm{Ab}$ & $5.3 \mathrm{Aa}$ \\
\hline HWEC (mg C kg-1) & $28.1 \mathrm{Ad}$ & $33.7 \mathrm{Ac}$ & $50.5 \mathrm{Ab}$ & 54.4 Aa \\
\hline $\mathrm{TC}\left(\mathrm{mg} \mathrm{C} \mathrm{kg}^{-1}\right)$ & 1059.7 Ad & $1282.0 \mathrm{Ac}$ & $1203.3 \mathrm{Ab}$ & $1430.7 \mathrm{Aa}$ \\
\hline GRSP (mg g-1) & $3.35 \mathrm{Ac}$ & $3.54 \mathrm{Ab}$ & $3.51 \mathrm{Ab}$ & $3.62 \mathrm{Aa}$ \\
\hline \multirow[t]{2}{*}{ EE-GRSP $\left(m g^{-1}\right)$} & $0.93 \mathrm{Ac}$ & $1.06 \mathrm{Ab}$ & $1.09 \mathrm{Ab}$ & $1.27 \mathrm{Aa}$ \\
\hline & \multicolumn{4}{|c|}{ Typic Argiudoll, Esperanza series } \\
\hline TOC $\left(\mathrm{g} \mathrm{kg}^{-1}\right)$ & $16.1 \mathrm{Ba}$ & $17.0 \mathrm{Ba}$ & $16.7 \mathrm{Ba}$ & $17.5 \mathrm{Ba}$ \\
\hline POC $\left(\mathrm{g} \mathrm{kg}^{-1}\right)$ & $2.9 \mathrm{Bc}$ & $3.4 \mathrm{Bb}$ & $3.5 \mathrm{Bb}$ & $4.3 \mathrm{Ba}$ \\
\hline HWEC (mg C kg-1) & $24.3 \mathrm{Bc}$ & $21.7 \mathrm{Bc}$ & $36.9 \mathrm{Bb}$ & 43.4 Ba \\
\hline $\mathrm{TC}\left(\mathrm{mg} C \mathrm{~kg}^{-1}\right)$ & $859.3 \mathrm{Bd}$ & $1170.7 \mathrm{Bc}$ & $1035.0 \mathrm{Bb}$ & $1276.0 \mathrm{Ba}$ \\
\hline GRSP (mg g-1) & $1.11 \mathrm{Bd}$ & $1.25 \mathrm{BC}$ & $1.83 \mathrm{Bb}$ & $1.86 \mathrm{Ba}$ \\
\hline EE-GRSP $\left(\mathrm{mg} \mathrm{g}^{-1}\right)$ & $0.92 \mathrm{Ac}$ & $1.06 \mathrm{Ab}$ & $1.08 \mathrm{Ab}$ & $1.24 \mathrm{Aa}$ \\
\hline
\end{tabular}

Different lowercase letters indicate differences between treatments for the same soil. Uppercase letters indicate differences between soils for the same treatment. Tukey test $(p<0.001)$. 
the Typic Hapludoll, Santa Isabel series, and $48 \%$ in the Typic Argiudoll, Esperanza series, evidencing the high sensitivity of this variable to changes in land management.

Concentrations of HWEC and TC increased in the following order: -pl -res $<-$ pl + res $<+$ pl -res $<+$ pl + res in Typic Hapludoll, Santa Isabel series. The increase in HWEC was notably smaller with the addition of residues $(22 \%)$ than that measured with plant roots $(82 \%)$. The best result was obtained when both sources of carbon were combined, i.e. + pl + res (96\%). This treatment also exhibits the larger value of TC, although the difference from -pl -res was notably smaller (35\%).

A similar trend was observed in the Typic Argiudoll, Esperanza series, except for the concentration of HWEC that did not differ between -pl -res and -pl + res treatments. However, the increase in HWEC caused by the presence of plant roots was $67 \%$, while the one verified with the $+\mathrm{pl}+$ res combination was $79 \%$. These values are unexpectedly inferior to those measured in the other soil, and may highlight the influence of soil texture on the activity of microorganisms and roots. The inclusion of residues and/or the existence of active roots also caused increases in concentration, to an even higher level $(48 \%)$ as compared with the value determined in Typic Hapludoll, Santa Isabel series.

Fungal activity, estimated through GRSP and EEGRSP, had a similar pattern to that of POC. In both soils the $+\mathrm{pl}+$ res treatment had a positive effect on EE-GRSP production. In contrast, the presence of active roots either alone or associated with residues stimulated the production of GRSP in Typic Argiudoll, Esperanza series $(69 \%)$.

The addition of organic matter (residues) to the soil increases the activity of decomposer microorganisms that produce mainly polysaccharides, which corroborates the findings of Cosentino et al. (1998). In contrast, the presence of active roots stimulates principally the activity of arbuscular mycorrhizal fungi and in some way the generation of HWEC, even though this activity seems to be strongly controlled by soil texture. Rillig and Steinberg (2002) found that the glomalin-related soil protein was produced in greater concentrations in poorly aggregated soils, as in the case of the Typic Argiudoll, Esperanza series. Moreover, fungal species (and communities) can differ to the extent to which they influence soil aggregation since fungal functioning depends strongly on the host plant identity (Rillig and Mummey, 2006; Duchicela et al., 2012). The enhancement of soil stability has been recently linked to shifts in soil fungal community composition (Duchicela et al., 2013). More studies are needed to establish the real contribution of the group of root-associated fungi (i.e. arbuscular mycorrhizal fungi) and the bacteria communities to the production of soil aggregating agents. This distinction may contribute to better definition of land management strategies that focus on recovering soil stability.
Effect of the treatments on the disaggregation mechanisms

Mean weight diameter for each pre-treatment did not differ in soils evaluated (FW $p<0.437, \mathrm{MB}$ $p<0.449$, SW $p<0.217$ ). In Typic Hapludoll, Santa Isabel series, aggregate stability decreased in the following order: SW (average MWD $1.92 \mathrm{~mm}$ ), > MB (average MWD $0.82 \mathrm{~mm}$ ), > FW (average MWD 0.37 $\mathrm{mm}$ ) (Figure 1). A similar trend was observed in the Typic Argiudoll, Esperanza series, in which the average MWDs were 1.56, 0.88 and $0.33 \mathrm{~mm}$ after SW, $\mathrm{MB}$ and FW pre-treatments, respectively (Figure 2). These variations are probably due to the conditions of wetting speed and energy applied to aggregates in each pre-treatment, as mentioned by Le Bissonnais (1996).

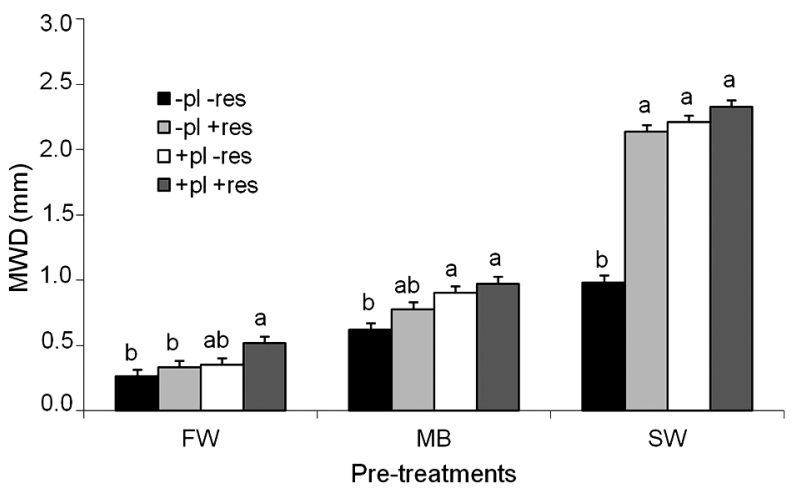

Figure 1 - Mean weight diameter (MWD) determined by fast wetting (FW), mechanical breakdown (MB) and slow wetting (SW) pretreatments on Typic Hapludoll, Santa Isabel series. Bars represent the standard error. Treatments with different letters indicate differences $(p<0.001)$.

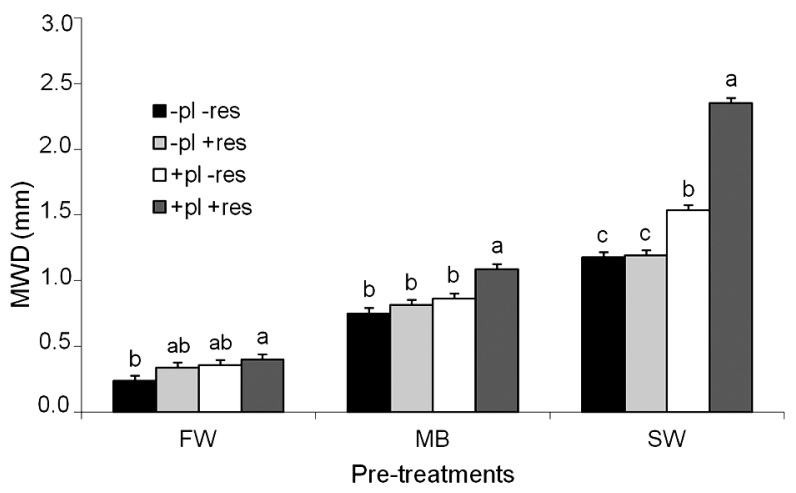

Figure 2 - Mean weight diameter (MWD) determined by the different fast wetting (FW), mechanical breakdown (MB) and slow wetting (SW) pre-treatments on Typic Argiudoll, Esperanza series. Bars represent the standard error. Treatments with different letters indicate differences $(p<0.001)$. 
In FW pre-treatment MWD ranged approximately between 0.2 and $0.5 \mathrm{~mm}$ in both soils. FW pre-treatment was the most destabilizing mechanism for structure breakdown which generated the lowest average MWD, while aggregates showed a more stable behavior against mechanical agitation (MB) and slow wetting (SW). Mean weight diameter values below $0.5 \mathrm{~mm}$ indicate aggregates slaking when wetted quickly. Therefore, aggregates from both soils exhibited very low stability against slaking, according to the classification proposed by Le Bissonnais (1996).

In MB pre-treatment MWD ranged approximately between 0.6 and $1.1 \mathrm{~mm}$ in both soils. Aggregates showed intermediate stability when they were subjected to mechanical agitation, which indicates they possess a degree of normal cohesion when occurrence of the slaking phenomenon is avoided.

In SW pre-treatment the highest MWD values were obtained regardless of soil and treatment; values ranged approximately between 0.9 and $2.5 \mathrm{~mm}$. SW involved a weak disruptive energy since aggregate wetting is performed progressively by capillary action and allows the escape of air with less aggregate destruction. These results may be due to the fact that nonexpandable clays predominate in both soils; thus, the differential colloid swelling which induces aggregate microcracking is limited. Soil behavior can be considered stable to very stable from the point of view of aggregate microcracking.

In general, ranges are in agreement with those reported by Cosentino et al. (2006) and Maqubela et al. (2012), who used the same method in silty-loam soils. In both soils, there was an MWD increase $(p<0.05)$ due to the effect of plant root $(+\mathrm{pl})$ and the addition of residues (+res) that caused an increase in aggregate resistance against the strong disruptive energy of the FW pretreatment compared to the control treatment (-pl -res) (Figures 1 and 2). Chenu et al. (2000) found that disintegration of intensively cultivated loam soils was predominantly attributed to the slaking forces. Cosentino et al. (2006) and Annabi et al. (2011) also observed that the slaking was the dominant process in reducing aggregation in silty-loam soils.

Figure 1 indicates that in Typic Hapludoll, Santa Isabel series, soil aggregate cohesion improved $(p$ 0.001 ) with the presence of plants and/or addition of residues regardless of the treatment. On the contrary, in the Typic Argiudoll, Esperanza series, all treatments showed a similar MWD, except for the + pl + res treatment which presented aggregates with higher $(p$ 0.001) MWDs (Figure 2). Aggregate resistance can be attributed to the presence of polysaccharide which increased particle cohesion as well as the effect produced by physical entanglement derived from root and fungal hyphae.

In the Typic Hapludoll, Santa Isabel series, the MWD of control treatment was lower $(p<0.001)$ than that observed in treatments with addition of crop resi- dues or plant root or a combination of both. In Typic Argiudoll, Esperanza series, the effect of the addition of crop residues alone did not result in significant differences compared with control. However, the treatment + pl showed higher MWD than control, and when it was combined with crop residues the highest MWD was obtained, similar to those found in the Typic Hapludoll, Santa Isabel series. These results indicate that the Typic Argiudoll, Esperanza series, presents less structural stability when confronting disruptive processes. Probably the greater fine silt content in the Typic Argiudoll, Esperanza series, (almost $30 \%$ ) and its reduced sand content have influenced results negatively. Soils with these characteristics have reduced structural stability and resilience, as indicated by Taboada et al. (2008), with little or no microcracking formation due to the predominance of a matrix that presents no expansion-contraction processes and little skeleton. Cosentino et al. (2006) and Annabi et al. (2011) also found limited aggregate breakdown in silty loam soils due to differential swelling in clay.

The presence of plants with active roots and/or organic residue addition tempers the effect of disintegration processes, although the mode of action appears to be different, as evidenced by the differential behavior of aggregates when faced with the breakdown mechanisms analyzed. In general, results show the biotic aggregation mechanism was more relevant than the abiotic one, which corroborates the results found by Chaudhary et al. (2009).

\section{Relationship between structural stability and ag- gregating agents}

The relationship between the various structural stability pre-treatments and aggregating agents in both soils was evaluated using canonical correlation analysis (Tables 3 and 4). Only the first canonical correlations

Table 3 - Canonical correlation analysis of variables related to carbon and variables of different structural stability pre-treatments in Typic Hapludoll, Santa Isabel series, and Typic Argiudoll, Esperanza series.

\begin{tabular}{lcc}
\hline Canonical variable & 1 & 2 \\
\hline $\mathrm{R}$ & 0.96 & 0.64 \\
$\mathrm{R}^{2}$ & 0.92 & 0.41 \\
Lambda & 34.26 & 6.66 \\
$\mathrm{p}$ - value & $6.1 \mathrm{E}-04$ & 0.35 \\
Variables related to carbon & & \\
POC & -0.24 & -2.31 \\
TOC & -0.27 & 0.91 \\
HWEC & 0.94 & 1.66 \\
TC & 0.55 & 0.25 \\
Structural stability pre- treatments & & \\
FW & 0.67 & -0.99 \\
MB & 0.19 & -0.74 \\
SW & 0.57 & 1.56 \\
\hline POC = particulate organic carbon: TOC $=$ total organic carbon; HWEC = hot
\end{tabular}

$\overline{P O C}=$ particulate organic carbon; $\mathrm{TOC}=$ total organic carbon; HWEC $=$ hot water-extractable carbohydrates; TC = total carbohydrates; FW = fast wetting; $\mathrm{MB}=$ mechanical breakdown; $\mathrm{SW}=$ slow wetting pre-treatments. 
Table 4 - Canonical correlation analysis of fungal variables and various structural stability pre-treatments in Typic Hapludoll, Santa Isabel series, and Typic Argiudoll, Esperanza series.

\begin{tabular}{lcc}
\hline Canonical variable & 1 & 2 \\
\hline $\mathrm{R}$ & 0.87 & 0.59 \\
$\mathrm{R}^{2}$ & 0.88 & 0.35 \\
Lambda & 43.05 & 13.46 \\
p-value & $2.9 \mathrm{E}-04$ & 0.68 \\
Fungal variables & & \\
GRSP & 0.06 & -1.03 \\
EE-GRSP & 0.98 & 0.31 \\
Structural stability pre-treatments & & \\
FW & 0.46 & 0.25 \\
MB & 0.37 & -1.58 \\
SW & 0.28 & 1.34 \\
\hline
\end{tabular}

GRSP = glomalin-related soil proteins; EE-GRSP = easily extractable soil proteins; $F W$ = fast wetting; $M B$ = mechanical breakdown; $S W=$ slow wetting pre-treatments.

were significant $(p<0.0001)$. In Table 3, the first canonical correlation accounted for $92 \%$ of the variability between the two groups of variables. The concentration of HWEC and CT were the variables most related to FW and SW pre-treatment MWDs, while TOC and POC had less importance. These results show quickly biodegradable organic fractions were those that conditioned structural stability the most, corroberated by the results found in soils of similar textures (Cosentino et al., 2006; Abiven et al., 2007; Maqubela et al., 2012).

Several researchers have shown that aggregate stability is positively correlated with TOC (Tisdall and Oades, 1982), while others indicate that it is more closely related to the content of water-extractable and/or total carbohydrates (Haynes, 2005; Degens, 1997; Liu et al., 2005). Furthermore, these substances are shown to act mainly on two out of the three mechanisms which cause aggregate breakdown: the slaking and microcracking. This effect is attributed to increased soil aggregate cohesion (Chenu and Guérif, 1991; Degens, 1997). HWEC, which represent a part of the soil organic carbon labile pool, and polysaccharides are basically produced by the activity of microorganisms, and act as active binding agents in relatively short periods of time, which has also been confirmed in this study since the effects were observed in one crop cycle (Haynes, 2005; Martins et al., 2009).

In relation to fungal variables, the first canonical correlation accounts for $88 \%$ of the variability between these two groups of variables (Table 4). The most influential fungal variable on MWD of the different pre-treatments was EE-GRSP. EE-GRSP fraction was positively associated to soil structural stability ( $p$ 0.001). EE-GRSP decreased all aggregate breakdown mechanisms, even if the effect was greater on the slaking (Table 4).

Fungal activity, evaluated by means of biomass, fungal hyphae length and ergosterol concentration, determine aggregate stability (Cosentino et al., 2006; Abiv- en et al., 2007; Annabi et al., 2007), although recent findings have been shown that mycorrhizal fungal species vary in their ability to aggregate the soils (Duchicela et al., 2012; Duchicela et al., 2013). The abundant production of glomalin by arbuscular mycorrhizal fungi, which are hydrophobic and recalcitrant by nature, contribute to the aggregate being stable (Wright and Upadhyaya, 1998; Rillig, 2005). These substances reduce slaking by way of altering the aggregate wetting rate and consequently increase structural stability (Guggenberger et al., 1999), which corroborates our observations in the present study. EE-GRSPs, by congregating together on aggregate particles, appear to form a protective film that helps to reduce microcracking and subsequent breakdown (Miller and Jastrow, 2000).

The presence of active roots, crop residues, and the biological activity that takes place associated with these components are key to improving aggregate formation and stabilization. The HWEC, TC and EE-GRSP seem to be determining elements in these processes, especially in loamy soils with scarce sand content. To achieve an improvement of silty loam soil structural quality it is necessary to establish a high rate of land use rotations, with crops producing high volumes of plant with active roots during the vegetative stage and subsequently crop residues since these aggregation biotic mechanisms are the most important in these soils.

\section{Conclusions}

Residue addition and the presence of active plant roots conditioned aggregation agents in both soils. The presence of polysaccharides and fungal activity linked to the production of proteins of the glomalin type were relevant in reducing soil disintegration, mainly the slaking mechanisms. Its effects were associated with increases in aggregate cohesion and alteration of the rate of wetting. Biotic aggregation mechanisms were the most important, especially in silty soils.

\section{References}

Abiven, S.; Menasseri, S.; Angers, D.A.; Leterme, P. 2007. Dynamics of aggregate stability and biological binding agents during the decomposition of organic material. European Journal of Soil Science 58: 239-247.

Amezketa, E. 1999. Soil aggregate stability: a review. Journal of Sustainable Agriculture 14: 83-151.

Annabi, M.; Houot, S.; Francou, C.; Poitrenaud, M.; Le Bissonnais, Y. 2007. Soil aggregate stability improvement with urban composts of different maturities. Soil Science Society of America Journal 71: 413-423.

Annabi, M.; Le Bissonnais, Y.; Le Villio-Poitrenaud, M.; Houot, S. 2011. Improvement of soil aggregate stability by repeated applications of organic amendments to a cultivated silty loam soil. Agriculture, Ecosystems and Environment 144: 382-389. 
Chaudhary, V.; Bowker, M.; O' dell, T.; Grace, J.; Redman, A.; Rillig, M.; Johnson, N. 2009. Untangling the biological contributions to soil stability in semiarid shrublands. Ecological Applications 19: 110-122.

Chenu, C.; Guérif, J. 1991. Mechanical strength of clay minerals as influenced by an adsorbed polysaccharide. Soil Science Society of America Journal 55: 1076-1080.

Chenu, C.; Le Bissonnais, Y.; Arrouays, D. 2000. Organic matter influence on clay wettability and soil aggregate stability. Soil Science Society of America Journal 64: 1479-1486.

Cosentino, D.; Costantini, A.; Segat, A.; Fertig, M. 1998. Relationships between organic carbon fractions and physical properties of an argentine soil under three tillage systems. Pesquisa Agropecuaria Brasileira 33: 981-986.

Cosentino, D.; Le Bissonnais, Y.; Chenu, C. 2006. Aggregate stability and microbial community dynamics under dryingwetting cycles in a silt loam soil. Soil Biology and Biochemistry 38: 2053-2062.

De Gryze, S.; Six, J.; Brits, C.; Merckx, R. 2005. A quantification of short-term macroaggregate dynamics: influences of wheat residue input and texture. Soil Biology and Biochemistry 37: 55-66.

Degens, B.P. 1997. Macro-aggregation of soils by biological bonding and binding mechanisms and the factors affecting these: a review. Australian Journal of Soil Research 35: 431459.

Denef, K.; Six, J. 2005. Clay mineralogy determines the importance of biological versus abiotic processes for macroaggregate formation and stabilization. European Journal of Soil Science 56: 469-479.

Dubois, M.; Gilles, K.; Hamilton, J.; Rebers, P.; Smith, F. 1956. Colorimetric method for determination of sugar and related substances. Analytical Chemistry 28: 350-356.

Duchicela, J.; Vogelsang, K.; Schultz, P.; Kaonongbua, W.; Middleton, E.; Bever, J. 2012. Non-native plants and soil microbes: potential contributors to the consistent reduction in soil aggregate stability caused by the disturbance of North American grasslands. New Phytologist 196: 212-222.

Duchicela, J.; Sullivan, T.; Bontti, E.; Bever, J. 2013. Soil aggregate stability increase is strongly related to fungal community succession along an abandoned agricultural field chronosequence in the Bolivian Altiplano. Journal of Applied Ecology 50: 1266-1273.

Gee, G.W.; Or, D. 2002. Particle-size analysis. p. 255-293. In: Dane, J.H.; Topp, G.C., eds. Methods of soil analysis. Part 4. Physical methods. Soil Science Society of America. Madison, WI, USA.

Guggenberger, G.; Elliott, E.T.; Frey, S.D.; Six, J.; Paustian, K. 1999. Microbial contributions to the aggregation of a cultivated grassland soil amended with starch. Soil Biology and Biochemistry 31: 407-419.

Haynes, R.J. 2005. Labile organic matter fractions as central components of the quality of agricultural soils: an overview. Advances in Agronomy 85: 221-268.

Hoagland, D.; Arnon, D. 1950. The water-culture method for growing plants without soil. University of California, Berkeley, CA, USA. (California Agricultural Experiments Station Circular, 347).
Instituto Argentino de Normalización y Certificación [IRAM]. 2007. IRAM-SAGPYA 29571-2. 2007 - Determination of Organic Matter in Soils. Part 2. Determination of Oxidable Organic Carbon by Sulfochromic Mixture in Soils. IRAM-SAGPYA, Buenos Aires, Argentine (in Spanish).

Irizar, A.; Andriulo, A.; Cosentino, D.; Améndola, C. 2010. Comparison of two physical fractionation methods for soil organic matter. Ciencia del Suelo 28: 115-121 (in Spanish, with abstract in English).

Le Bissonnais, Y. 1996. Aggregate stability and assessment of soil crustability and erodibility. I. Theory and methodology. European Journal of Soil Science 47: 425-437.

Liu, A.; Ma, B.L.; Bomke, A.A. 2005. Effects of cover crops on soil aggregate stability, total organic carbon, and polysaccharides. Soil Science Society of America Journal 69: 2041-2048.

Maqubela, M.; Muchaonyerwa, P.; Mnkeni, P. 2012. Inoculation effects of two South African cyanobacteria strains on aggregate stability of a silt loam soil. African Journal of Biotechnology 11: 10726-10735.

Martins, M.; Corá, J.E.; Jorge, R.F.; Marcelo, A.V. 2009. Crop type influences soil aggregation and organic matter under no-tillage. Soil and Tillage Research 104: 22-29.

Materechera, S.A.; Kirby, J.M.; Alston, A.M.; Dexter, A.R. 1994. Modification of soil aggregation by watering regime and roots growing through beds of large aggregates. Plant and Soil 160: 57-66.

Miller, R.M.; Jastrow, J.D. 2000. Mycorrhizal fungi influence soil structure. p. 4-18. In: Kapulnik, Y.; Douds, D., eds. Arbuscular mycorrhizas: physiology, molecular biology and ecology. Kluwer, Dordrecht, The Netherlands.

Pecorari, C.; Guerif, J.; Stengel, P. 1990. Phytoliths in soils of the pampean region. Influence on the physical properties determining the elementary mechanisms of structure evolution. Ciencia del Suelo 8: 135-141 (in Spanish, with abstract in English).

Portella, C.; Guimarães, M.; Feller, C.; Batista Fonseca, I.; Tavares Filho, J. 2012. Soil aggregation under different management systems. Revista Brasileira de Ciência do Solo 36: 1868-1877 (in Portuguese, with abstract in English).

Puget, P.; Angers, D.; Chenu, C. 1999. Nature of carbohydrates associated with water-stable aggregates of two cultivated soils. Soil Biology and Biochemistry 31: 55-63.

Rillig, M.C. 2004. Arbuscular mycorrhizae, glomalin, and soil aggregation. Canadian Journal of Soil Science 84: 355-363.

Rillig, M.C. 2005. A connection between fungal hydrophobins and soil water repellency? Pedobiologia 49: 395-399.

Rillig, M.C.; Steinberg, P.D. 2002. Glomalin production by an arbuscular mycorrhizal fungus: a mechanism of habitat modification. Soil Biology and Biochemistry 34: 1371-1374.

Rillig, M.C.; Mummey, D.L. 2006. Mycorrhizas and soil structure: Tansley review. New Phytologist 171: 41-53.

Sasal, M.C.; Andriulo, A.; Taboada, M. 2006. Soil porosity characteristics and water movement under zero tillage in silty soils in Argentinean Pampas. Soil and Tillage Research 87: 9-18.

Six, J.; Elliott, E.; Paustian, K. 2000. Soil structure and soil organic matter: II. A normalized stability index and the effect of mineralogy. Soil Science Society of America Journal 64: 10421049. 
South Atlantic Modern Language Association [SAMLA]. 2004. Methodological Support System for Soil Testing Laboratories. SAMLA, Atlanta, GA, USA (in Spanish).

Taboada, M.; Barbosa, O.; Rodríguez, M.; Cosentino, D. 2004. Mechanisms of aggregation in a silty loam under different simulated management regimes. Geoderma 123: 233-244.

Taboada, M.; Barbosa, O.; Cosentino, D. 2008. Null creation of air-filled structural pores by soil cracking and shrinkage in silty loamy soils. Journal of Soil Science 173: 130-142.

Tisdall, J.M.; Oades, J.M. 1982. Organic matter and water-stable aggregates in soils. Journal of Soil Science 33: 141-163.
Varela, M.; Fernandez, P.; Rubio, G.; Taboada, M. 2011. Cover crops: effects on soil macroporosity and soil structural stability in a silt loam soil. Ciencia del Suelo 29: 99-106 (in Spanish, with abstract in English).

Wright, S.; Upadhyaya, A. 1996. Extraction of and abundant and unusual protein from soil and comparison with hyphal protein of arbuscular mycorrhizal fungi. Journal of Soil Science 161: 575-586.

Wright, S.; Upadhyaya, A. 1998. A survey of soils for aggregate stability and glomalin, a glycoprotein produced by hyphae of arbuscular mycorrhizal fungi. Plant and Soil 198: 97-107. 